\title{
Negotiation of US Beef Imports in Taiwan
}

\section{Shin-Jye Lee ${ }^{1}$; Hsueh-Cheng Liu ${ }^{1}$;Ching-Hsun Tseng ${ }^{2}$; Ying-Yi Chou ${ }^{1}$}

Affiliation: Institute of Management of Technology, National Chiao Tung University, Taiwan ${ }^{1}$; Department of Computer Science, University of Manchester, United Kingdom²

E-mail: camhero@gamil.com ${ }^{1}$; stdm11528@gmail.com ${ }^{2}$; hank131415go61@gmail.com ${ }^{3}$; shiaopooh1811@gmail.com ${ }^{4}$

DOI: 10.26821/IJSRC.9.4.2021.9417

\begin{abstract}
US beef imports in Taiwan is always a popular issue of how to make an optimal negotiation under a complete trade-off. A potential 'non-obvious' solution or creative compromise based on the integrative bargaining is that Taiwan government may imports conditional U.S. beef (boneless beef and cow internal organs, except beef mince), and the U.S. government may offer the visa free of the U.S. entering (after one year) and provide the advanced military procurement (more advanced military equipment) in the next military procurement.
\end{abstract}

Keywords: Negotiation, US Beef Import

\section{INTRODUCTION}

The issue of importing U.S. beef in Taiwan started in 2007. Under the pressure applied by the U.S. government, the Taiwan government considered that accepted U.S. beef imports can effectively promote the successful signing of "Taiwan-US Trade and Investment Framework Agreement (TIFA)", the probability of visa free to the U.S., and it is therefore able to strengthen the relationship between Taiwan and U.S. In the other hand, according to the record, U.S. beef had many problems, including the problem of mad cow disease (or Bovine Spongiform Encephalopathy, BSE) and that of the residue of clenbuterol and ractopamine. These problems directly caused the closure of overseas markets of U.S. beef imports, and Taiwan government also decided to block U.S. beef imports in 2003. Meanwhile, some oriental countries, such as Japan, Korean and other countries, have reopened the markets of U.S. beef by lowering the standard of ractopamine residues of the overseas imported beef. Hence, reopen the markets of U.S. beef becomes a controversial issue in Taiwan, because it not only involves the food safety issues, but it also involves the trade issue and political issues between
Taiwan and U.S. On 27 April 2012, the joint proposal of the opposition parties for blocking U.S. beef imports had been proposed in Taiwan Legislative Yuan, and the negotiation of U.S. beef imports therefore starts.

\section{THE MAIN PARTIES INVOLVED AND THE INSTITUIONAL AND HISTORICAL CONTEXT FOR THE NEGOTIATION}

Parties involved in the negotiation of U.S. beef imports consists of ruling party of Taiwan government (KMT), opposition parties of Taiwan government (DDP, PFP, TSU), and U.S. government.

\subsection{The Ruling Party of Taiwan Government (Kuomintang, KMT)}

KMT is currently the ruling party of Taiwan government, and each decision of KMT will bring the direct impact to the institution and people in Taiwan. So far as the position of KMT towards the issue of U.S. beef imports is concerned, KMT wish the bill of U.S. beef imports can be successfully passed, because which can potentially promote the signing of "TaiwanUS Trade and Investment Framework Agreement (TIFA)", increasing the probability of visa free of the U.S. entering, and further increase the negotiation chips in the military procurement with U.S. government (which be able to smoothly force U.S. to sell more advanced military equipments to Taiwan, such as F16 A/B, AMRAAM, E-2, Knox FF-1052, Perry FFG-7, P-3, OH-58D, AH-1Q, Javelin, and so on). Most important of all, the result of each decision made by KMT directly brings the influence to the political achievements of KMT-led government and further makes a great impact on the next election.

\subsection{The Opposition Parties of Taiwan Government (DDP, PFP, TSUP)}

There are currently three primary opposition parties in Taiwan, including Democratic Progressive Party 
Volume 9 Issue 4 April 2021

(DDP), People First Party (PFP), and Taiwan Solidarity Union (TSU). All of these opposition parties definitely oppose to import the beef containing clenbuterol from U.S. So far as the political position is concerned, the position of opposition parties is somewhat similar with that of KMT, because each political proposal proposed by the opposition parties will directly make a great impact on the next election.

\subsection{The U.S. Government}

To expand the overseas market of U.S. beef for easing the domestic economic problem, the U.S. government insists on a either strong or firm position on the issue of importing U.S. beef to Taiwan markets, and the U.S. government considers that the current standard of ractopamine residues of U.S. beef is fully satisfied with the human healthy without harm, which is supported by a number of scientific experiments done by Japan, China, and European Union. The U.S. government also considers that the problem of ractopamine residues exists in the domestic beef in Taiwan as well, and the closure of Taiwan markets of U.S. beef containing ractopamine residues conducted by Taiwan government is inconsistent with the scientific evidence. Further, the U.S. government considers that Taiwan government is actually building the security barrier of trade, especially for banning U.S. beef imports. Basically, the U.S. government aims to import the U.S. beef and the relevant products to Taiwan markets, including boneless beef, beef with bone, cow internal organs and beef mince.

\section{THE INTERESTS OF THE PARTIES AND HOW INTERESTS HAVE BEEN MAPPED ONTO THE POSITIONS TAKEN IN THE NEGOTIATIONS}

\subsection{U.S. Beef Imports Issue}

1) KMT - this issue is very important to KMT. The first choice for KMT is to conditionally import U.S. beef, the beef containing very small ractopamine residues and low potential BSE-infected products, such as boneless beef (cattle aged lower 30 months old). This arrangement either satisfies the request of U.S. government or ensures the safe U.S. beef importing to Taiwan, and this is a win-win arrangement for KMT. However, it would be unacceptable for KMT to import all of U.S. beef products. As the beef containing excessive ractopamine residues and the high potential BSE-infected products (e.g. beef with bone, cow internal organs and beef mince) are imported to Taiwan markets, the safety issue of health will arise immediately. Also, the KMT may probably lose its position of ruling party in Taiwan government.

2) The Opposition Parties (DDP, PFP, TSUP) - this issue is also important to them. The first choice for the opposition parties is to fully reject all U.S. beef imports, because they think this arrangement either protect the health of people or potentially make a positive impact on the next election. The same with KMT, it would be unacceptable for the opposition parties to import all of U.S. beef products to Taiwan. The reason is the same with KMT, because the opposition parties (DDP, PFP, TSU) may probably lose the election again.

3) The U.S. Government - it is very important to the U.S. government. The first choice for the U.S. government is to fully import U.S. beef and the relevant products to Taiwan, including boneless beef, beef with bone, cow internal organs and beef mince. However, it would be unacceptable for the U.S. Government to import nothing about U.S. beef products to Taiwan. This is because the U.S. government cannot ease the domestic problem by benefiting form U.S. beef imports.

\subsection{Taiwan-US Trade and Investment Framework Agreement (TIFA) Issue}

1) KMT - this issue is very important to KMT. The first choice for KMT is successfully complete the signing of TIFA. In addition to promote the relationship between Taiwan and U.S., this also can be considered as a great diplomatic achievement. It therefore brings certain advantage to lead the KMT to win the next election. However, it would be unacceptable for KMT to unsuccessfully the signing of TIFA, because this will decrease the credit of KMT-led government in Taiwan.

2) The Opposition Parties (DDP, PFP, TSU) - this issue is not important to them, because the opposition parties cannot benefit from the successfully signing of TIFA conducted by the ruling party (KMT). However, if the opposition parties can help KMT to complete the signing of TIFA, it may gain some credits from the people and increase the credits for the next election.

3) The U.S. Government -it is somewhat important to the U.S. government. The first choice for the U.S. government is successfully complete the signing of TIFA, and this can promote the relationship between Taiwan and U.S. The TIFA may also potentially bring the positive impact to the U.S. economic. However, it would be also acceptable for the U.S. government to fail the signing of TIFA with Taiwan, because it does not bring a huge impact to U.S. economic once it has 
Volume 9 Issue 4 April 2021

been completed.

\section{HOW AWARE ARE PARTIES OF THEIR OWN BATNA AND TO WHAT EXTEN HAVE THEY SOUGHT TO EMPLOY A COMPETITIVE OR COOPERATIVE STRATEGY?}

\subsection{KMT}

Before the negotiation of U.S. beef imports with the U.S. government, KMT gathers the information (e.g. position, interest, requirement, priority, limitation, and deadline) of other parties as detailed as possible, and analyzes as well as understands the potential position, interest, and requirement of other parties. So far as the negotiation with the opposition parties is concerned, KMT adopts the cooperative strategy with the compromising mode, and KMT bargains over interests rather than positions with the opposition parties. In addition to the same position - bring the health foods to the people, the interests of the opposition parties aim to bargain more political benefits. KMT also adopts the thinking of "bargaining over interests", so KMT promises the opposition parties to pass certain economic bills proposed by the opposition parties. Therefore, KMT made an agreement with the opposition parties. The opposition parties agreed the conditional U.S. beef imports. So far as the negotiation with the U.S. government is concerned, KMT also tries to adopt the cooperative strategy with the compromising mode, because KMT understands the probable position, interest and requirement of the U.S. government. The interest of U.S. government aims to expand the overseas markets of U.S. beef by importing the full U.S. beef to Taiwan markets. Based on bargain over interests, KMT tries to provide Taiwan markets for other products instead of the full U.S. beef.

\subsection{The Opposition Parties (DDP, PFP, TSU)}

As described before, the opposition parties understands that the final interest of KMT aims to successfully complete the signing of TIFA, and a successful negotiation of U.S. beef imports with the U.S. government can largely promote this achievement. Based on bargain over interests, the opposition parties bargainmore political benefits from KMT by agreeing the conditional U.S. beef imports.

\subsection{The U.S. Government}

The U.S. government adopts a competitive strategy in this negotiation. The U.S. government understands that Taiwan really needs to get TIFA. In addition, the U.S. government bargains the full U.S. beef imports by giving other offers, including the probability of visa free of the U.S. entering and the advanced military procurement.

\section{Examples of framing or anchoring in the negotiations}

KMT - So far as the anchoring in the negotiation of U.S. beef imports is concerned, KMT sets the anchor of "conditional U.S. beef imports (only boneless beef)", as this anchor has already been negotiated with the opposition parties. So far as the framing in the negotiation of U.S. beef imports is concerned, KMT builds a frame for the integrative bargaining, which focuses on the overall interests rather than individual positions. KMT represented that KMT could therefore has more opportunity to pass the economic bill proposed by the opposition parties if the opposition parties agree the U.S. beef imports, because it can further promote the successful signing of TIFA. In addition, KMT represented that if the U.S. government can offer the more advanced military procurement and visa free of the U.S. entering, Taiwan may positively accept the U.S. beef imports.

\section{CONCLUSION}

As the opposition parties have the same position with KMT -bring the health foods to the people, the opposition parties trust KMT will not agree the full U.S. beef imports in the negotiations. In addition, the long run reputation of KMT also makes people trust that KMT will not do harms to Taiwan in the negotiation of U.S. beef imports. In addition, the expertise analysis indeed helps KMT to effectively identify the information of other parties in the negotiation. 